\title{
The Impact of the Growth Rate of the Gross Domestic Product (GDP) on Poverty Reduction in Nigeria
}

\author{
Olanrewaju Makinde Hassan - Ph.D ${ }^{1}$ \\ ${ }^{1}$ Department of Business Administration, Faculty of Management Sciences, Kogi State University, Anyigba, Kogi \\ State, Nigeria \\ Correspondence: Olanrewaju Makinde Hassan - Ph.D, Department of Business Administration, Faculty of \\ Management Sciences, Kogi State University, Anyigba, Kogi State, Nigeria. Tel: 234-80-3379-7404
}

Received: June 24, 2015

Accepted: July 29, 2015

Online Published: September 17, 2015

doi:10.5430/ijba.v6n5p90

URL: http://dx.doi.org/10.5430/ijba.v6n5p90

\begin{abstract}
This study is on the impact of GDP growth rate on poverty reduction in Nigeria. The study made use of secondary data sourced from the Central Bank of Nigeria statistical bulletin and the National Bureau of Statistics between 1986 and 2012. The model for the study has as its dependent variable the Unemployment rate whose reduction should imply poverty reduction and its explanatory variable is the GDP growth rate. Using the Ordinary Least Square (OLS) regression techniques; our study revealed that the there is a weak relationship between the unemployment rate and the Nigerian Gross Domestic Product (GDP) growth rate and that instead of an inverse relationship, it was positive. That is, as GDP was growing the unemployment rate was also growing. The study holds that when citizen cannot work to earn they will remain poor. This implies that the GDP growth has not impacted positively on the poor through job creation sufficient enough to reduce the percentage of the unemployed and the incidence of poverty over the period of study. We therefore recommend that there is the need to reassess the growth direction so as to give priority to key sectors like the agricultural and the industrial sectors that have the capacity to generate and absorb more labours thereby solving employment problem and at the same reducing the poverty incidence on the citizens.
\end{abstract}

Keywords: impact, gross domestic product, growth rate, poverty, reduction, key sectors

\section{Introduction}

Poverty reduction has become a central goal for development. It can be achieved by economic growth and/or by the distribution of income. Issues related to the benefits of growth accrued to the poor have become a priority of development policy in the 1990s (Son \&Kakwani, 2004). There is little doubt that economic growth contributes significantly to poverty alleviation. The evidence is mounting and coming from various sources: cross-country analyses (Besley and Burgess, 2003; Dollar and Kraay, 2005; Kraay, 2006; and López, 2004), cross-regional and time-series comparisons (Ravallion and Chen, 2007; Ravallion and Datt, 2002), and the evaluation of poverty evolution using household data (Bibi, 2005; Contreras, 2001; Menezes-Filho and Vasconcellos, 2004). At the same time, it is clear that the effect of economic growth on poverty reduction is not always the same.

Infact, most studies point to considerable heterogeneity in the poverty-growth relationship, and understanding the sources of this divergence is a growing area of investigation (Bourguignon, 2003; Kakwani, Khandker, and Son, 2004; Lucas and Timmer, 2005; and Ravallion, 2004).

The Nigerian national capacity as reflected in the recently rebased GDP cannot be played down; because the nation's economy currently ranked as the largest in Africa, the challenge however, has been how this economic strength can be used to engender sustainable growth and poverty reduction. This study therefore, intends to look at the relevance of the growth in the GDP to poverty reduction in Nigeria between 1991 and 2012.

\subsection{Statement of the Problem}

The persistent problem of poverty in the developing world has led many to question the efficacy of economic growth and development as a means of poverty alleviation (Roemer and Gugerty, 1997). Indeed, the lack of convergence in standards of living across countries is one of the great unresolved issues in development and growth economics. In Nigeria for example, the incidence of poverty and the rate of unemployment in Nigeria have increased significantly between 2004 and 2011 (NES, 2012). Within that time, incidence of poverty rose from 54.4\% in 2004 to $69 \%$ in 
2010. In other words, the number of Nigerians living in poverty rose from 68.7 million in 2004 to 112.5 million in 2010. In the same period, the unemployment rate rose from $13.4 \%$ to $21.4 \%$. It then rose further to $23.9 \%$ in 2011 . Whereas, the GDP within the same period also has been growing at an average of $6 \%$ per annum between 2004 and 2011 (NES, 2012). This growth in GDP no doubt has placed the nation's economy on the frontline in Africa in terms of capacity. It is the aim of this paper to find out whether the GDP growth is impacting positively on poverty incidence in Nigeria.

\subsection{Research Questions}

The research questions that shall guide this study are;

i. Is GDP growth rate compatible with poverty reduction in Nigeria?

ii. If not, why is the GDP growth rate not bringing about poverty reduction in Nigeria?

\subsection{Objectives of the Study}

The objectives of this study are:

i. To examine the impact of the GDP growth rate on poverty reduction strategy in Nigeria.

ii. To find out why the GDP growth has not been bringing about commensurate poverty reduction through job creation.

\subsection{Research Hypothesis}

The hypotheses that shall guide this study are as stated thus:

\section{Hypothesis one}

$\mathbf{H}_{\mathbf{0}}$ : GDP growth rate has not impacted on poverty reduction in Nigeria.

$\mathbf{H}_{\mathbf{a}}$ : GDP growth rate has impacted on poverty reduction in Nigeria.

\section{Hypothesis two}

$\mathbf{H}_{\mathbf{0}}$ : There are no factors responsible for the lack of impact of GDP growth rate on poverty reduction in Nigeria?

$\mathbf{H}_{\mathbf{a}}$ : There are factors responsible for the lack of impact of GDP growth rate on poverty reduction in Nigeria?

\subsection{Significance of the Study}

The significance of a study aimed at examining the impact of GDP growth rate on poverty reduction in Nigeria cannot be over-emphasized, given the fact the Nigerian GDP has been growing at an average of $6 \%$ per annum between 2004 and 2011. As such, doing a study that would help to find out the extent to which this GDP growth rate has impacted upon poverty reduction should be considered apt and necessary. This is because; the study findings could serve as veritable tool for government policy planners and executors. In addition, it will add to existing literatures and a reference for scholars and future researchers in this area.

\section{Literature Review}

\subsection{Conceptual Framework}

The concept of poverty has a multi-disciplinary dimension for the economist; however, poverty can be properly situated within the realm of development economics. Central to the quest for policies and programmes that will reduce poverty is the issue of the conceptualization of poverty. Conceptually, three dominant views are identified as the meaning of poverty in the literature (Oyeranti and Olayiwola, 2005).

According to Oyeranti and Olayiwola (2005), the first view sees poverty as a severe deprivation of some basic human needs at the individual or household level. Put differently, poverty is a material deprivation, and this can be assessed in monetary terms. While this conceptualization of poverty makes the quantitative analysis of poverty straightforward and permits comparisons over time and between countries, it fails to recognize non-material forms of deprivation such as illiteracy and social discrimination among others. The second view has a direct link with the work of Sen (1999), and it defines poverty as the failure to achieve basic capabilities such as being adequately nourished, living a healthy life, possession of skills to participate in economic and social life, permission to take part in community activities to mention a few. This conceptualization forms the basis for the belief that poverty is multi-dimensional. Although, the capabilities framework offers many advantages over the income-consumption conceptualization, yet it is argued by Karlsson (2001) that it requires a greater variety of data and that no consensus exists on how capability deprivation at the household level is to be computed. 
The third conceptualization of poverty came into limelight in the 1990s and has a fundamentally different approach to the understanding of poverty: subjective poverty assessments. Karlsson (2001) presented five conclusions from the voices of the poor series, these are:

a) Poverty needs to be viewed in a multi-dimensional way. Hunger is part of everyone's understanding of poverty. Equally strong is the sense of powerlessness, voicelessness, and humiliation that comes with being poor.

b) The state has been ineffective. People everywhere fear police, they hate corruption, and they trust only their own institutions.

c) Non-governmental organizations play a limited role. People rely on informal networks.

d) Households are under deep stress. Gender relations are crucial to understanding poverty, particularly the positions of men.

e) The social fabric is often poor people's saving grace, and it is under threat.

Measuring Poverty: In a study by Roemer and Gugerty (1997), they put forward that there are many indicators available for measuring poverty; in a cross country analysis the choice of indicator will be limited by the need for a consistent cross-country measure. While this study relies on income distribution data such as that described above, it is useful to review briefly the major tools used in the definition of poverty and in the conversion of national data to internationally comparable standards. The welfare approach to poverty alleviation typically used by economists assumes both that individuals know what is best for themselves and that monetary measures of consumption or income can serve as an indicator of well-being (Roemer and Gugerty, 1997). Using this approach, the analyst defines a poverty line as a level of income, and all those under that line are considered poor. Under an alternative non-welfarist approach, standards of nutritional or other basic human needs are defined by the observer, who then estimates the income level needed to satisfy those needs. That required level of income becomes the poverty line. The welfare approach associates the standard of living with individual consumption, generally measured using expenditure data, and wherever possible including consumption from own production. Where expenditure data are not available, income can be taken as a proxy for consumption. Most of the data on poverty measures now available are based on comprehensive household surveys. This is the ideal form of survey, particularly if it is national in scope. One issue that arises in using household surveys to measure poverty is that the survey unit is the household, whereas we want to measure the welfare of individuals. If household income were the unit of analysis, then when comparing two households with equal per capita income, the larger household would wrongly appear to have higher welfare than the smaller one. Where only household information is possible, some kind of conversion to an individual (per capita) basis is necessary (Deaton and Muellbauer, (1980).

A poverty line can be defined in absolute or relative terms. An absolute poverty line is set in terms of a particular living standard, defined in a common currency and held constant for all the countries, regions, or areas under consideration. One example might be setting an absolute poverty line at $20 \%$ of the U.S. median income and using this income level as the cut-off to define poverty in all countries. An alternative approach is to define poverty at a certain dollar income per day; one dollar a day is a common poverty line for developing countries. Absolute poverty levels imply a certain command over goods and services necessary to rise above poverty. To make poverty lines comparable across countries, economists generally prefer to calculate income or expenditure on a purchasing power parity, or PPP basis. PPP takes into account the differences in relative prices, and therefore purchasing power, among different countries. One dollar typically buys more basic goods and services in India than in the United States, and that should be taken into account when estimating living standards. A relative poverty line is set at a constant proportion of the mean or median income in a country, for example, $25 \%$ or $50 \%$ or even $100 \%$ of mean or median income. Each country thus has a different relative poverty line, expressed in dollars, and each country's relative poverty line changes as incomes rise. If we use $50 \%$ of median income as a relative poverty line and compare the U.S. and a developing country, clearly those with incomes equal to $50 \%$ of the median in the U.S. will have income levels higher than those at $50 \%$ of the median in a developing country like India, even after converting expenditures or income to common (PPP) dollar prices. Once a method for defining a poverty line has been chosen, the analyst must then decide how exactly to measure those individuals below the poverty line. Three measures of poverty are commonly used (Foster, Greer and Thorbecke (1984), Atkinson (1987) and Foster and Shorrocks (1988) and Ravallion (1992)): $\mathrm{n}$ the headcount index (HCI), which measures the prevalence of poverty; $\mathrm{n}$ the poverty gap index $(P G I)$, which measures the depth of poverty; and $\mathrm{n}$ the Foster-Greer-Thorbecke ( $F G T$ ) index that measures the severity of poverty. A great deal of theoretical work has gone into defining consistent and equitable poverty measures during the last 25 years. Unfortunately, when analyzing developing countries the data are often poor enough that these measures are difficult to calculate reliably. Nevertheless, we present a brief description of the 
major indicators. The headcount index (HCI), the proportion of the total population considered to be poor, is defined as the fraction of the population whose standard of living (income or expenditure) is below the poverty line. The headcount index is relatively easy to estimate and easy to communicate. It is quite useful in addressing overall changes in poverty. The key weakness in this measure is that it only measures changes of income that cross the poverty line and ignores shifts below the poverty line. If a poor person becomes poorer, this is not reflected in the headcount index. The poverty gap index (PGI) alleviates some of this problem by measuring the aggregate amount of poverty relative to the poverty line. The poverty gap represents the transfer of income to the poor that would be necessary to eliminate poverty, assuming an absolute poverty line. The poverty gap index is simply the average poverty gap across the entire population. The main weakness with the poverty gap index is that it does not indicate the severity of poverty. For example, suppose there are two countries. In Country A all of the poor all have incomes just below the poverty line. In Country B there are two groups of poor: one subgroup has incomes just below the mean and the other has much lower incomes. The poverty gap index is averaged across all the poor and could therefore mask the desperate poverty of the very poor group in the second country. The Foster-Greer-Thorbecke measure is sensitive to this problem of extreme poverty. It is most commonly defined as the square of the poverty gap, divided by the population. By using the square of the poverty gap, the $F G T$ gives heavier weight than the $P G I$ to the poverty of the very poor, because all income gaps are squared. In the example above of two countries with the same headcount and poverty gap indices, the Foster-Greer-Thorbecke index will be higher for the second country with the group of desperately poor. The drawback to this method is that it is less straightforward to interpret. It is essentially composed of two parts: an amount due to the poverty gap and an amount due to inequality among the poor. The choice of poverty indicator does not matter if the distribution of income has not changed within the society. When all members of society have gained income in equal proportion, then all of the measures discussed above will lead to the same poverty ranking. If instead poor individuals clustered around the poverty line gain in income, while the poorest households lose, the headcount index will register a decrease in poverty while the $F G T$ index might rise. If, however, income from individuals grouped around the mean is redistributed to the poorest, the HCI could stay the same while the $F G T$ could decline.

\subsection{The Debate over Poverty Reduction Strategies}

Roemer and Gugerty (1997) hold that most economists believe that economic growth benefits nearly all citizens of a country, even if not equally, and therefore reduces poverty. The extent to which these benefits are realized by various groups is reflected as change (or lack of change) in the distribution of income. If economic growth raises the incomes of everyone in a society in equal proportion, then the distribution of income will not change. Two arguments are often made against the proposition that economic growth reduces poverty. First, the Kuznets curve hypothesis proposed by economist Simon Kuznets in 1955 holds that as incomes grow in the early stages of development, income distribution would at first worsen and then improve as a wider segment of the population participated in the rising national income. If income distribution became dramatically less equal with growth, poverty might not be declining. Our study finds that income distribution does not change dramatically in most countries, even over relatively long periods of time. In addition, the data in this paper indicate that the Kuznets hypothesis does not seem to hold for most individual countries that are currently developing. Second, the obvious depth and persistence of poverty has created doubts about the ability of economic growth to reduce poverty; these doubts are especially prevalent among development professionals working directly with the poor in developing countries. In addition, stabilization and structural adjustment measures that are prescribed to promote growth are widely perceived to deepen poverty, particularly in the short run, casting further doubt on the wisdom of attacking poverty through faster growth. While there is little empirical evidence on the relationship between structural adjustment and poverty alleviation, this paper demonstrates that the policies promoted by structural adjustment, namely openness to the world economy and sound fiscal and macroeconomic management, do tend to reduce poverty through their effects on growth. Unfortunately, other than through the effect of raising incomes, few data are available to address the relationship between economic growth and the welfare of the very poorest members of society.

\subsection{Economic Structure and Income Distribution}

As noted above, for growth to occur without a reduction in poverty, income distribution must become more unequal (Roemer and Gugerty, 1997). Could rapid growth take place without any reduction in poverty? It is possible but unlikely, as many studies now show. Moreover, it is possible for income distribution to worsen somewhat while the incomes of the poor nonetheless increase. The extent to which a given rate of growth affects poverty depends upon many factors, but particularly on economic structure and economic policies. Growth is more likely to lead directly to a reduction in poverty when the economic assets of a country are distributed relatively equally or when economic 
growth is based on the intensive employment of abundant factors of production, which for most countries is labor (Roemer and Gugerty, 1997).

In largely rural economies based on small-scale farming, as in many African and Asian countries, most of the poor are engaged in agriculture. When such a country grows through agricultural exports, or when growth in manufacturing increases the demand for food and materials supplied by the rural sector, growth benefits both poor farmers and the even poorer labourers they employ. In land-poor but labour-abundant economies, such as those of East Asia, rapid growth of manufactured or service exports creates a large pool of new jobs, absorbs the supply of low-productivity workers, and eventually causes a rise in real wages that further reduces poverty (Roemer and Gugerty, 1997). In contrast, mineral-rich economies typically have very concentrated income distributions; the country's wealth is in very few hands. Thus, when growth comes from mineral exports, the market mechanisms that would involve the lower income groups in that growth are weak (Roemer and Gugerty, 1997). The 3 best means for poverty alleviation in such countries may involve government programs to channel mineral revenues to the poor through education, health, rural works and other activities that will attract private employers. Development strategy and economic policies may also have differential impacts on the reduction of poverty via their impact on growth. Economic strategies and policies also affect distribution by altering the way an economy generates and absorbs economic growth. Outward looking policies, for example, encourage a country to intensify its production in industries that employ abundant, and therefore low-cost, resources. If these economies are either labor-abundant or both land- and labor-abundant, these policies will enhance the impact of growth on poverty alleviation (Roemer and Gugerty, 1997). But if the economy is mineral-rich, or if it has concentrated agriculture in the hands of a few wealthy landowners, the impact on poverty will be weak. The market reforms espoused in structural adjustment should enhance the impact of growth on poverty. The reduction in controls reduces rent-seeking, which tends to concentrate income and wealth. More importantly, it opens market access to a wider group of participants, including the powerless and the poor. This effect can be especially strong when the controls that are targeted for elimination have affected the rural economy, such as export marketing boards, price and marketing restrictions on food grains, or when they have restricted entry to the informal sector, especially rural trading and curb side retailing in cities. The analytic arguments presented here suggest that growth tends to reduce poverty and that openness and outward trade orientation decrease poverty through their effects on growth. The data presented in this paper support these assertions.

\subsection{Empirical Evidence on Growth and Poverty Reduction}

The early hypothesis of the Kuznets curve led to a large development literature on the potential for economic growth to widen inequality and worsen the plight of the poor, a phenomenon called immiserizing growth (Robinson (1976), Adelman and Robinson (1989), Papanek and Kyn (1981). The initial studies on the Kuznets curve hypothesis used cross-sectional data and compared poor countries to rich countries in order to test hypotheses about income distribution and growth. As data covering longer time periods for individual countries have become available, the evidence points in the opposite direction: growth appears to lessen poverty.

Even early studies like Ahluwalia, Carter and Chenery (1979) and Fields (1980) found that increases in poverty and economic growth were a very exceptional combination. A 1979 study of 12 growth periods in various countries found no increase in poverty and the real per capita income of the poorest $20 \%$ rose in every period of growth. A more recent study by Fields (1989) indicates that of 18 countries with data on poverty over time, in only one case was economic growth not accompanied by a fall in poverty. Moreover, Fields found that more rapid economic growth tends to bring greater declines in poverty. While this preliminary evidence was encouraging, more conclusive results were precluded by the lack of data. In 1996, however, a new database was compiled by Klaus Deininger and Lyn Squire at the World Bank. This database contains the most comprehensive data that exist on income distribution across countries. The data cover 58 countries, beginning in 1960, and for each country give the distribution of income by quintile. In compiling the database, every effort was made to ensure that only reasonably high quality data based on comprehensive household surveys were included. Of the 58 countries included in the database, 26 are developing countries. The database makes it possible for the first time to test propositions about the Kuznets curve and the relationship between growth and poverty over time. We used the Deininger-Squire data set to identify 61 intervals, covering 26 developing countries, for which growth in national average and quintile incomes could be identified. We used relatively restrictive criteria in defining our sample: intervals should be at least 5 years in length, but as long as a decade if possible, and based on consistently defined household surveys.

Using the same data set but including all 58 countries, Deininger and Squire (1996b) identify 91 intervals or episodes for which income growth and changes in income distribution are available. They find that changes in income 
distribution are generally small, so that growth is clearly associated with increasing incomes in each quintile of the population. In more than $81 \%$ of their 91 growth episodes, the incomes of the poorest quintile rose. Another study by Ravallion and Chen (1996) analyzes a more selective set of household survey results, covering the period since 1980. Their results are striking and give strong support to the hypothesis that growth reduces poverty in developing countries. Ravallion and Chen use 64 intervals that cover periods from one to seven years. Twenty-one of these intervals are from Eastern Europe and Central Asia (former Soviet or transitional countries), and forty-three are from developing countries. For each episode, Ravallion and Chen calculate the change in the headcount index of poverty $(\mathrm{H})$ and the growth in the mean income for the sample as a whole.

A great deal of evidence has been generated in the last five years that supports the proposition that more open economies have higher rates of growth. This section reviews the main findings of these studies. An important study by Dollar (1992) looks at the relationship between exchange rates and growth by constructing a measure of openness indicating the extent to which the trade regime distorts the real exchange rate from its free-trade level for the period 1976-1985 and uses this indicator in a regression of 95 countries. Dollar estimates that reducing the level of exchange rate distortion to that of Asia would raise GDP growth by $1.8 \%$ in Africa and $0.7 \%$ in Latin America. Reducing exchange rate variability to the Asian level would add an additional $0.8 \%$ to annual growth in Latin America and $0.3 \%$ to growth rates Africa. Sachs and Warner test the effects of openness on growth using their openness variable described above. In regressions of the annual growth of per capita GDP from 1970 to 1989, incorporating data for 114 countries, Sachs and Warner find large, negative and highly significant coefficients for the openness variable. Open economies have annual growth rates as much as 2.8 percentage points higher than closed economies, on average. Sachs (1996) has used these results to show how much faster African countries could grow if they adopt the kind of open policies that have characterized East and Southeast Asian countries. He attributes a difference of $1.8 \%$ a year in income growth to the closed-economy policies of African countries, including exchange rate overvaluation, import restrictions and export restrictions (marketing boards). Two other factors--lower savings rates 12 and less efficient internal markets--reduce growth rates by another $2.8 \%$ a year below Asian levels, so that on the whole different policies can explain $4.6 \%$ of the difference between African and Asian growth rates. Using a different regression framework, Easterly and Levine (1996) find that three variables associated with soundly managed, open economies--the exchange rate premium, the fiscal surplus as a share of GDP, and ratio of liquid financial assets to GDP--can account for a growth differential of 1.5 percentage points between African economies and East and Southeast Asian economies.

These studies focus on the relationship between growth and economic structure. A study by Fischer (1993) investigates the effects of shorter-term, macroeconomic variables with longterm growth. Fischer finds that low budget deficits (or higher surpluses), low inflation and market-based official exchange rates13 are associated strongly and significantly with more rapid economic growth. By extension, then, sound macroeconomic management, because it establishes conditions for sustainable growth, is associated with reduced poverty. Finally, in their study of six African countries cited above, Demery and Squire (1996) construct an index that measures the combined effects of three macroeconomic policies: a reduction in the fiscal deficit, a reduction in seignorage, and a devaluation of the real effective exchange rate. They find that in all six countries, a favourable change in the macroeconomic policy index was associated with a favourable change in the incidence of poverty. In Cote d'Ivoire, the only country with increased poverty, the macroeconomic index worsened. These studies all demonstrate the important connection between outward oriented policies and economic growth. Because economic growth is such a key factor in poverty reduction, openness becomes an important policy variable that can be used to reduce poverty. But economic structure and government spending decisions also matter, as discussed below.

\subsection{Poverty and Economic Structure}

Countries that are relatively rich in natural resources tend to have slower economic growth (Roemer and Gugerty, 1997). Furthermore, for reasons already discussed, in resource-rich societies the distribution of income is expected to be more concentrated and market forces alone will be less effective in translating GDP growth into substantial reductions in poverty. Thus, on both counts, we would expect the growth of income of the poorest groups to be slower in resource-rich economies. To test this proposition, we utilized three indices compiled by Sachs and Warner to represent resource endowment: the ratio of natural resource exports to GDP the ratio of natural resource exports to total exports the ratio of arable, pasture, and forest land to population. All indices are based in 1971, a year predating all but a few of our observations and thus indicative of an initial resource endowment.

The results are qualitatively similar to those on openness. Resource exports as a share of total exports and land per person have a negative effect on growth. The coefficients are negative and significant at the $1 \%$ level or better. 
Growth of incomes for the poor is lower in well-endowed economies. But resource endowment does not explain much of the variance in income growth of the poor: adjusted R-squareds are below $25 \%$. And, as with openness, when the growth of GDP is inserted into these regressions, the resource endowment coefficients lose significance, though they retain the expected negative sign. Resource endowments appear to work against poverty reduction through their depressing effect on economic growth, as Sachs and Warner (1995b) have demonstrated. Regressions were run showing the effects of openness and resource endowment on income growth of the poor. Regressions 1 and 2 use the share of resource exports in total exports as the indicator of natural resource wealth. All coefficients are negative and all but one is significant at the $5 \%$ level or better. This indicates that high levels of resource exports are associated with lower growth rates. The openness variables are positive; the positive impact of an open economy can offset the negative impact of resource dependence. In regressions 3 and 4, land is used as the indicator of resource wealth, and the story is broadly similar, though only one of the coefficients on openness is significant at the $5 \%$ level. Resource wealth in terms of land appears to have a negative effect on growth. None of these regressions, however, explains more than a third of the variance in income growth of the poorest. When the growth of GDP per capita is included, the openness and resource endowment variables lose their significance, although the signs remain the same. Openness retains its positive sign, suggesting again an open economy may help to offset the negative impact of resource dependence. As in the regressions above, the openness and resource variables appear to have little or no impact on poverty that is separable from their impact on economic growth.

\subsection{Theoretical Framework: The Resource Curse}

In considering the curse of resource wealth on poverty reduction, it is important to keep in mind a few outliers: resource-rich countries that have enjoyed both rapid GDP growth and dramatic reductions in poverty. Indonesia and Malaysia, both rich in natural resources including petroleum, have had rapid growth in GDP per capita since 1970 and substantially reduced poverty. In Indonesia, for example, average incomes grew by 4\% a year from 1970 to 1993 and the headcount index of poverty fell from $60 \%$ to under $15 \%$. In Malaysia, per capita income grew by over $3 \%$ a year and the headcount index of poverty fell from $18 \%$ to $2 \%$ over the same period. These countries avoided the curse of wealth through shrewd government policies. First, both governments maintained sound macroeconomic policies that avoided exchange rate overvaluation and other symptoms of Dutch disease during the resource booms of the 1970s. Second, they invested in the education and health of their people, especially of the rural poor. Third, Indonesia (and to a lesser extent Malaysia) invested in rural infrastructure and agricultural development that benefited agricultural smallholders, especially on densely populated Java. And fourth, Malaysia undertook a determined policy of redistribution of assets and jobs towards the majority Malay population, which included most of the poor. Resource wealth does not condemn a country to entrenched poverty. Instead, resource wealth can be turned to an advantage in the war on poverty, but it takes a determined and skilful government to do so. It is the political economy of resources that drives the growth and poverty results.

In Nigeria, there is abundance of resource wealth of both human and natural endowments. Yet this resource wealth cohabit with abject poverty, reasons been that these human and natural resources have not been properly harnessed to bring about commensurate impact on the poverty of her citizen. This is the resource curse syndrome. However, recent happenings with the rising GDP could be suggesting that the economy is been revamped. This position is what this study aimed to test what has been the impact of this rising GDP on poverty situation in the country.

\section{Research Methodology}

\subsection{Specification of the Model}

In specifying the model, it takes queue from the Kuznets hypothesis proposed by economist Simon Kuznets in 1955; which holds that as incomes grow in the early stages of development, income distribution would at first worsen and then improve as a wider segment of the population participated in the rising national income. What this intuitively transformed to mean is that income spreads when citizens can work and earn income. As such, if the GDP growth rate represents economic growth, then the unemployment rate can represent the poverty reduction index. It is expected that as the economy grows income distribution should lessen the hold of poverty through employment generation as an aftermath of the growth. Therefore, a model in which the dependent variable is the annual time series data of Nigerian unemployment rate (UNEMrt) while the independent variable is the gross domestic product (GDP) from 1991-2011, can be specified in the form:

$$
\begin{gathered}
\mathrm{Y}=\mathrm{f}\left(\mathrm{X}_{1}\right) \\
\mathrm{Y}=\mathrm{bo}+\mathrm{b}_{1} \mathrm{X}_{1}+\mathrm{U}
\end{gathered}
$$

Where; 
$\mathrm{Y}=$ Unemployment rate (FPI)

$\mathrm{X}_{1}=$ Gross Domestic Product growth rate (GDPgr)

$\mathrm{U}=$ the stochastic variable or the error term and $b_{1}$, is the coefficients of the parameter estimate of the variable $\mathrm{X}_{1}$, and $\mathrm{b}_{\mathrm{o}}$ the intercept of the Model.

As such, we used the ordinary least square multiple regression technique to estimate the values of the parameters $b_{0}$ and $b_{1}$. Besides, we will also conduct the student's t-test and the standard error test to know and to test the statistical significance of the parameter estimates respectively, and the test of goodness of fit for the model using the $\mathrm{R}^{2}$ and adjusted $\mathrm{R}^{2}$ techniques. This will enable us to know the percentage of variations between the dependent variable and the explanatory variables which very central to helping to understanding the impact of economic growth on poverty reduction.

And finally, we conduct the F-statistic test to determine the overall significance of the regression model and the Durbin -Watson test for the presence or absence of autocorrelation.

\subsection{Expected Result}

On apriori ground, it is expected that fall in unemployment rate should be spurred by rising GDP growth rate; as such unemployment rate should have a negative relationship with the gross domestic products growth rate. Since, it is expected that as the GDP grows there should be poverty reduction through employment generation resulting from the growth.

\subsection{Estimation Techniques and Data Sources}

In the estimation of the specified model, the ordinary least square (OLS) multiple regression technique was employed. The estimation will be carried out with the use of an econometric package known as 'E-Views'. In order to facilitate time series analysis, data on, FPI, GDP, interest rate, exchange rate and market capitalization were collected from the following sources: Central Bank Nigeria (CBN) - Statistical Bulletin and National Bureau of Statistics (NBS).

\section{Presentation and Analysis of Results}

\subsection{Presentation of Results}

Using the annual time series data of the entire variables so chosen, we have our estimated model result to be:

\begin{tabular}{llll}
\hline Dep. Var. = UNEMrt & Coefficient & Standard Error & t-statistics \\
\hline Intercept $\{\mathrm{c}\}$ & 3.98 & 2.27 & 1.75 \\
\hline GDPgr & 1.14 & 0.39 & 2.91 \\
\hline & & & \\
\hline & $\mathrm{R}^{2}=0.25$ & F-stat=8.46 (Prob. 0.0) & d.w. $=0.43$ \\
\hline
\end{tabular}

Source: Author's computations

\subsection{Interpretation of Results}

\subsubsection{On Apriori Grounds or Economic Relationships}

The explanatory variable's parameter estimate possesses a positive sign. This implies that the GDP growth rate and the unemployment rate have a positive relationship. This does not conform to apriori since it has positive sign instead of negative sign. It was expected that as the GDP grows it should generate employment opportunities thereby reducing the incidence of poverty through income distribution.

\subsubsection{On Statistical Criterion}

i. Based on the coefficient values, a unit rise (instead of a fall) in the unemployment rate is caused by 1.14rise in the GDP growth rate. That is, as the GDP growth rate was rising the unemployment rate was also rising alongside. This is not in line with expected theoretical propositions. Using the rule of thumb of 2, it is evident that the t-value for the parameter estimate of the variable was statistically significant. This was also not expected to be since the relationship was wrongly signed. 
ii. The $\mathrm{R}^{2}$ value of 0.25 shows that there is very weak relationship between the dependent variable unemployment rate and the independent or explanatory variables the GDP growth rate. The model has been able to explain only about $25 \%$ of the relationship or variations; this is highly insignificant. This validates the fact that the GDP growth rate has not in any spur poverty reduction by its inability to reduce the unemployment rate.

iii. The F-stat; of 32.77 with probability value 0.00 assumes a very huge value when compared with the table value of 5.95. This implies that in the overall, our model is statistically significant in explaining the relationship between FPI and the explanatory variables.

\subsubsection{Econometric Criterion}

Using the Durbin-Watson value of 0.14 , this value is much closer to zero (0) and it falls outside the critical region or the region of indecision, this suggests the presence of positive autocorrelation.

\subsection{Policy Implications of Results}

The statistical significance of the GDP growth rate estimate given that the relationship with the explanatory variable was wrongly signed implies that the GDP growth has not been creating sufficient jobs to reduce the unemployment rate in the economy over the period of study. The reason for this is not far-fetched since the international flow of foreign investment into Nigeria has been encouraged by various economic policies within the period, following the internationalization of the capital market in 1995 and the abrogation of laws that constrained foreign participation in the Nigerian capital market. The non-statistically significance of other parameter estimates of GDP, interest rate and the exchange rate implies that a country's GDP size, interest rate and exchange rate do not necessarily determine the flow of international currency into the Nigerian economy.

\section{Conclusion and Recommendation}

The result of the estimate showed that in spite the Nigerian GDP growth rate employment opportunities have not grown sufficiently to mitigate the poverty incidence on the army of the unemployed in the economy. This finding is in line with the content of the communique of the Nigerian Economic Society (2012) when they put forward that the optimism about GDP growth which averaged over 6\% annually in 2004-2011 is counter balanced by the sustained growth in the rate of unemployment and rising incidence of poverty and inequality. They stated further that this paradox of jobless growth poses a significant threat to economic, social and political stability. This study has revealed that the Nigerian economy over time has been growing but not sufficient to reduce the poverty incidence on the populace through job creation. Hence, we made our recommendations based on the results that, it is important that we become interested in the direction of the growth of the growth of GDP so as to ascertain whether the economy while growing also have absorptive capacity to create room more jobs or employments for the army of the unemployed in the economy. As a result priority should be given to those sectors like the agricultural and the industrial sectors that will be able to generate and absorb more labours thereby solving employment problem and at the same reducing the poverty incidence on the citizens.

\section{References}

Adelman, I., \& Robinson, S. (1989). Income Distribution and Development. In Cheneryand Srinivasan (Eds.), Handbook of Development Economics (Vol. 2). Amsterdam: New Holland. http://dx.doi.org/10.1016/S1573-4471(89)02006-1

Ahluwalia, M., Carter, N. G., \& Hollis B. Chenery. (1979). Growth and Poverty in Developing Countries. Journal of Development Economics, 3, 307-342. http://dx.doi.org/10.1016/0304-3878(76)90027-4

Anand, S., \& Harris, C. (1992). Issues in the Measurement of Undernutrition. In S. Osmani (Ed.), Nutrition and Poverty. Oxford: Oxford University Press.

Atkinson, A. (1975). The Economics of Inequality. Oxford: Oxford University Press.

Atkinson, A. B. (1987). On the Measurement of Poverty. Econometrica, 55(4), 749-764. http://dx.doi.org/10.2307/1911028

Atkinson, A. B. (1991). Comparing Poverty Rates Internationally: Lessons from Recent Studies in Developed Countries. World Bank Economic Review, 5(1), 3-21. http://dx.doi.org/10.1093/wber/5.1.3

Bennell, P. (1996). Rates of Return to Education: Does the Conventional Pattern Prevail in Sub-Saharan Africa. World Development, 23(1), 183-199. http://dx.doi.org/10.1016/0305-750X(95)00115-S

Blackburn, M. (1994). International Comparisons of Poverty. The American Economic Review, 84(2), 371-374. 
Bourgignon, Francois, \& Christian Morrison. (1990). Income Distribution, Development and Foreign Trade: A Cross-Sectional Analysis. European Economic Review, 34, 1113-1132. http://dx.doi.org/10.1016/0014-2921(90)90071-6

Bourguignon, Francois, Jaime de Melo, \& Christian Morrisson. (1991). Poverty and Income Distribution during Adjustment: Issues and Evidence from the OECD Project. WorldBank Country Economics Department, Working Paper 810.

Bruno, Michael, Martin Ravallion, \& Lyn Squire. (1996). Equity and Growth in Developing Countries: Old and New Perspectives on the Policy Issues. World Bank, Policy Research Working Paper1563.

Chauduri, S., \& Ravallion, M. (1994). How Well do Static Welfare Indicators Identify the Chronically Poor?. Journal of Public Economics, 53(3), 367-394. http://dx.doi.org/10.1016/0047-2727(94)90031-0

Deaton, A., \& Muellbauer, J. (1980). Economics and Consumer Behavior. Cambridge: Cambridge University Press. http://dx.doi.org/10.1017/CBO9780511805653

Deininger, K., \& Squire, L. (1996a). Does Inequality Matter? Re-examing the Links between Growth and Equity. Mimeo.

Deininger, K., \& Squire, L. (1996b). Measuring Income Inequality: A New Data-Base. Mimeo.

Deininger, K., \& Squire, L. (1996c). New Ways of Looking at Old Issues: Inequality and Growth. Mimeo.

Demery, L., \& Squire, L. (1996). Macroeconomic Adjustment and Poverty in Africa: An Emerging Picture. World Bank Research Observer, 11(1), 39-59. http://dx.doi.org/10.1093/wbro/11.1.39

Dollar, D. (1992). Outward Oriented Economies Really Do Grow More Rapidly: Evidence from 95 LDCs, 1976-1985. Economic Development and Cultural Change, 40, 523-44. http://dx.doi.org/10.1086/451959

Easterly, W., \& Levine, R. (1996). Africa's Growth Tragedy: Policies and Ethnic Divisions. Harvard Institute for International Development, Development Discussion Paper 536.

Fields, G. (1980). Poverty, Inequality, and Development. Cambridge: Cambridge University Press. http://dx.doi.org/10.1017/CBO9780511572173

Fields, G. (1989). Changes in Poverty and Inequality in Developing Countries. The World Bank Research Observer, 4(2), 167-182. http://dx.doi.org/10.1093/wbro/4.2.167

Fischer, S. (1993). The Role of Macroeconomic Factors in Growth. Journal of Monetary Economics, 32, 485-512. http://dx.doi.org/10.1016/0304-3932(93)90027-D

Foster, J., \& Shorrocks, A. (1988). Poverty Orderings. Econometrica, 56(1), 173-177. http://dx.doi.org/10.2307/1911846

Foster, J., Greer, J., \& Thorbecke, E. (1984). A Class of Decomposable Poverty Measures. Econometrica, 52(3), 761-766. http://dx.doi.org/10.2307/1913475

Kakawani, N. (1980). On a Class of Poverty Measures. Econometrica, 48(2), 437-446. http://dx.doi.org/10.2307/1911106

Karlsson. (2001). Opening Address. In Pleskovic, B and N Stern (Eds.), Annual World Bank Conference on Development Economic 2000, pp.7-11.

Morley, S. (1995). Poverty and Inequality in Latin America: The Impact of Adjustment and Recovery in the 1980's. Baltimore: Johns Hopkins University Press.

NES. (2012). Nigerian Economic Society (NES) Communiqué.

Oyeranti and Olayiwola. (2005). Policies and Programmes for poverty reduction in rural Nigeria, an interim research report submitted to the African economic research consortium.

Papanek, G., \& Kyn, O. (1986). The Effect of Income Distribution on Development, the Growth Rate, and Economic Strategy. Journal of Development Economics, 23, 55-65. http://dx.doi.org/10.1016/0304-3878(86)90079-9

Ravallion, M. (1992). Poverty Comparisons: A Guide to Concepts and Methods. World Bank LSMS Working Paper 88.

Ravallion, M., \& Chen, S. H. (1996). What Can New Survey Data Tell us About Recent Changes in Living Standards in Developing and Transitional Economies. Mimeo, Poverty and Human Resources Division, Policy Research 
Department, World Bank.

Ravallion, M., \& Datt, G. (1996). How Important to India's Poor is the Urban-Rural Composition of Growth?. World Bank Economic Review, 10-11.

Ravallion, M., \& Huppi, M. (1991). Measuring Changes in Poverty: A Methodological Case Study of Indonesia during an Adjustment Period. World Bank Economic Review, 5(1), 57-82. http://dx.doi.org/10.1093/wber/5.1.57

Robinson, S. (1986). A Note on the U-hypothesis Relating Income Inequality and Economic Development. American Economic Review, 66, 437-440.

Roemer, M., \& Gugerty, M. K. (1997). Does Economic Growth Reduce Poverty? Harvard Institute for International Development: Technical Paper.

Sachs, J. (1996, June). Growth in Africa: It Can be Done. The Economist, 29, 19-21.

Sachs, J., \& Warner, A. (1995a). Economic Convergence and Economic Policies. Harvard Institute for International Development, Development Discussion Paper 502.

Sachs, J., \& Warner, A. (1995b). Natural Resource Abundance and Economic Growth. Harvard Institute for International Development, Development Discussion Paper 517 a.

Sen, A. (1976). Poverty: An Ordinal Approach to Measurement. Econometrica, 44(2), $219-232$. http://dx.doi.org/10.2307/1912718

Sen, A. (1979). Personal Utilities and Public Judgements: Or What's Wrong with Welfare Economics?. The Economic Journal, 89, 537-558. http://dx.doi.org/10.2307/2231867

Sen. (1999). Development as Freedom. Oxford University Press, New York.

Squire, L. (1993). Fighting Poverty. American Economic Review, 83(2), 377-382.

The World Bank. (1990). World Development Report 1990. London: Oxford University Press. 